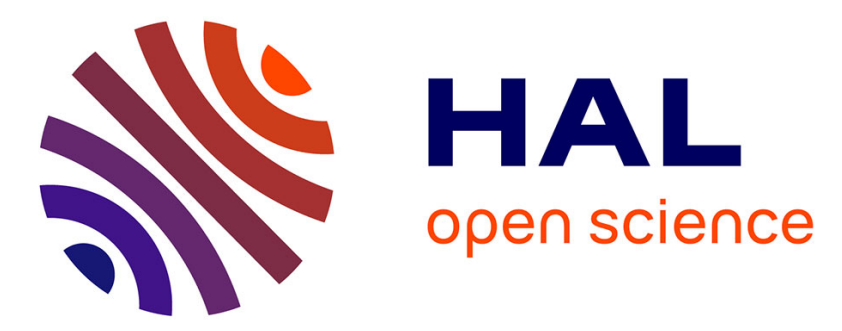

\title{
Birch bark tar and jewellery: the case study of a necklace from the Iron Age (Eckwersheim, NE France)
}

Blandine Courel, Philippe Schaeffer, Clément Féliu, Yohann Thomas, Pierre Adam

\section{- To cite this version:}

Blandine Courel, Philippe Schaeffer, Clément Féliu, Yohann Thomas, Pierre Adam. Birch bark tar and jewellery: the case study of a necklace from the Iron Age (Eckwersheim, NE France). Journal of Archaeological Science: Reports, 2018, 20, pp.72-79. 10.1016/j.jasrep.2018.04.016 . hal-02324638

\section{HAL Id: hal-02324638 \\ https://hal.science/hal-02324638}

Submitted on 22 Oct 2019

HAL is a multi-disciplinary open access archive for the deposit and dissemination of scientific research documents, whether they are published or not. The documents may come from teaching and research institutions in France or abroad, or from public or private research centers.
L'archive ouverte pluridisciplinaire HAL, est destinée au dépôt et à la diffusion de documents scientifiques de niveau recherche, publiés ou non, émanant des établissements d'enseignement et de recherche français ou étrangers, des laboratoires publics ou privés. 


\title{
Version avant révision
}

\section{Birch bark tar and jewellery: the case study of a necklace from the Iron Age (Eckwersheim, NE France)}

\author{
${\text { Blandine } \text { Courel }^{\mathrm{a},{ }^{*}, 1} \text {, Philippe Schaeffer }}^{\mathrm{a}}$, Clément Féliu ${ }^{\mathrm{b}, \mathrm{c}}$, Yohann Thomas $^{\mathrm{b}}$, Pierre Adam ${ }^{\mathrm{a}}$ \\ ${ }^{a}$ Université de Strasbourg, CNRS, CHIMIE, UMR 7177, F-67000 Strasbourg, France \\ ${ }^{b}$ INRAP Grand-Est, F-67100 Strasbourg, France \\ ${ }^{c}$ Université de Strasbourg, Université de Haute Alsace, CNRS, ArchIMèdE UMR 7044, F- \\ 67000 Strasbourg, France
}

\section{Abstract}

Organic residue analysis has been undertaken on an organic material found on a necklace with a pendant unearthed from a necropolis dated to the Early Iron Age (800-475 BC) and located in Eckwersheim (NE France). The molecular composition of the substance, which was investigated using gas chromatography coupled to mass spectrometry, points towards an adhesive used to stick two bronze half-spheres to form a pendant. The predominance of triterpenoids from the lupane series led to the identification of the adhesive as a birch bark tar and constitutes a rare example of the use of such a material in jewellery in the past.

Keywords: birch bark tar, conifer resin, Early Iron Age, necklace, jewellery, lupane-related triterpenoids.

\section{Introduction}

Archaeological evidence of birch bark tar, an adhesive substance obtained by dry pyrolysis of birch bark (e.g. Regert et al., 1998; Koller et al., 2001; Rageot et al., 2015), is abundantly documented in the literature. Considered as one of the first man-made organic material, birch bark tar is frequently present among archaeological finds dated from the Neolithic period in Europe and its first use by Neanderthalians is dated back to the Palaeolithic (Koller et al.,

\footnotetext{
* Corresponding author.

${ }^{1}$ Present address : The British Museum, Great Russell Street, London WC1B 3DG

E-mail addresses: BCourel@britishmuseum.org (B. Courel), p.schaef@unistra.fr (P. Schaeffer), clement.feliu@inrap.fr (C. Féliu), yohann.thomas@inrap.fr (Y. Thomas), padam@unistra.fr (P. Adam).
} 


\section{Version avant révision}

2001). This sticky and hydrophobic material has been used for many purposes such as the hafting of lithic or bone tools (e.g. Regert et al., 1998; Koller et al., 2001), the reparation and waterproofing of pottery (e.g. Binder et al., 1990; Charters et al., 1993; Connan et al., 2000; Urem-Kotsou et al., 2002; Rageot et al., 2015), the decoration of ceramics (e.g. Vogt, 1949; Trąbska et al., 2011; Rageot et al., 2015) and, more surprisingly, as chewing-gum (e.g. Aveling and Heron, 1999; van Gijn and Boon, 2006; Karg et al., 2014). The identification of birch bark tar mainly relies on the detection of lupane-related triterpenoids as diagnostic molecular biomarkers. These compounds possess indeed ideal features since lupane-related triterpenoids are abundant in birch tar and their assemblage can be considered as highly specific (Hayek et al., 1989; Schnell et al., 2014). In addition, these compounds are relatively resistant to various alteration processes such as biodegradation which probably accounts for their good preservation even in ancient archaeological samples dating back to the Palaeolithic and Mesolithic Periods (Koller et al., 2001; Aveling and Heron, 1998).

We report here the investigation by gas chromatography-mass spectrometry (GC-MS) of the lipid content of a dark organic substance of unknown nature that has served to assemble two bronze half-spheres in order to form the pendant of a necklace (Fig. 1) dating to the Hallstatt D1 period (625-550 BC). Due to the predominance of lupane-related triterpenoids in the lipid extract, their origin (genuine biological compounds vs. triterpenes altered by natural or anthropic processes) is discussed in the light of the molecular investigation of reference samples of birch bark and birch bark tars.

\section{Materials and method}

\subsection{Archaeological sample}

Sample A (INRAP - Institut National de Recherches Archéologiques Préventives - reference number: PRL BG 6008-02) corresponds to a dark substance found between two small bronze 


\section{Version avant révision}

half-spheres which were assembled to create the pendant of a necklace (Fig. 1). The jewellery was uncovered among the furniture and artefacts of the tomb 6008 unearthed at Eckwersheim (Alsace, NE France) by an INRAP team led by Dr. Clément Féliu and Dr. Yohann Thomas. The tomb was dated to the Early Iron Age and the necklace between $625 \mathrm{BC}$ and $550 \mathrm{BC}$ (Hallstatt D1 period).

\subsection{Reference samples}

The reference samples comprise: (1) the lipid extract of pieces of birch bark (Betula pendula) from a trunk in an advanced state of alteration (sample B); (2) the lipid extract of pieces of the same birch bark sample pyrolysed with a heat gun during 10 minutes under $\mathrm{N}_{2}$ atmosphere (sample C); (3) a birch bark tar from Betula pendula prepared by descending distillation (sample D, reference number 162/5 2018 00, Dr. Andreas Kurzweil, Museumsdorf Düppel, Berlin, Germany).

\subsection{Lipid analysis}

Samples A - D were extracted by sonication using a mixture of dichloromethane/methanol $\left(\mathrm{CH}_{2} \mathrm{Cl}_{2} / \mathrm{CH}_{3} \mathrm{OH}, 1: 1, \mathrm{v} / \mathrm{v}\right)$ followed by filtration of the supernatant through celite and removal of the solvent under reduced pressure. An aliquot of the extract in $\mathrm{CH}_{2} \mathrm{Cl}_{2}$ was acetylated $\left(\mathrm{Ac}_{2} \mathrm{O}, \mathrm{N}\right.$-methylimidazole, $30 \mathrm{~min}$, ambient temperature $)$ and, after removal of the solvents and excess reagents, treated with a solution of diazomethane in diethylether to methylate the carboxylic acids. The derivatised crude extract was fractionated on a silica gel column into an apolar fraction eluted with $\mathrm{CH}_{2} \mathrm{Cl}_{2} / \mathrm{EtOAc}(8: 2, \mathrm{v} / \mathrm{v})$ which was analysed by GC-MS and a more polar fraction eluted with $\mathrm{CH}_{2} \mathrm{Cl}_{2} / \mathrm{CH}_{3} \mathrm{OH}(1: 1$, v/v) which was not further investigated. 


\section{Version avant révision}

71 GC-MS analyses were carried out using a Thermo Trace gas chromatograph (Thermo

Scientific) equipped with an autosampler Tri Plus, a programmed temperature vaporizing (PTV) injector and a HP5-MS column (30 m x $0.25 \mathrm{~mm}$ i.d. x $0.25 \mu \mathrm{m}$ film thickness) using He as carrier gas (constant flow rate at $1.1 \mathrm{ml} / \mathrm{min}$ ). Temperature program: $70{ }^{\circ} \mathrm{C}-200{ }^{\circ} \mathrm{C}$ $\left(10{ }^{\circ} \mathrm{C} / \mathrm{min}\right), 200{ }^{\circ} \mathrm{C}-300{ }^{\circ} \mathrm{C}\left(4{ }^{\circ} \mathrm{C} / \mathrm{min}\right)$, isothermal at $300{ }^{\circ} \mathrm{C}(40 \mathrm{~min})$. The mass spectrometer was operating in the electron ionization (EI) mode at $70 \mathrm{eV}$ with a scan range of 50 to $700 \mathrm{~m} / z$. The data were investigated using Xcalibur Software and mass spectra were compared with the NIST library and literature data.

\section{Results and discussion}

\subsection{Triterpenoids of the lupane series: birch bark as main ingredient}

GC-MS analysis of the organic extract of the substance from the pendant (sample A) led to the identification of specific triterpenoids from the lupane series, indicating a predominant contribution from an angiosperm source. These triterpenoids comprise, notably, lupeol $\mathbf{1}$ (numbers refer to structures presented in the Appendix), betulin $\mathbf{2}$, lupenone $\mathbf{3}$, betulone $\mathbf{4}$, lupanone 5 and lupan-3,28-diol 6 (Fig. 2) which are important triterpenes of birch bark (Hayek et al., 1990; Krasutsky, 2006; Schnell et al., 2014). The predominance of the same compounds among the lipids of the reference birch bark samples B-D (Fig. 3) was thus not unexpected. Betulin 2, in particular, largely predominates the gas chromatogram of the lipids from the birch bark sample B, representing ca. $60 \%$ of the apolar lipids. The identification of triterpenoids from the lupane series in the archaeological sample A points thus clearly to birch bark tar which may have been used as an adhesive material. It can be proposed that bark of either Betula pendula (silver bitch) or Betula pubescens (downy birch) served as raw material for the preparation of the adhesive since they are the most common Betula species in Europe (Beck et al., 2016). 


\section{Version avant révision}

\subsection{Altered triterpenoids as markers for ageing and thermal treatment}

The distribution of the triterpenoids in the archaeological sample (Fig. 2) is, however, significantly different from that observed with fresh birch bark (Fig. 3). This can likely be explained by the various alteration processes affecting triterpenoids upon the thermal treatment used for the preparation of the substance, in addition to other processes induced by oxidative ageing and/or by diagenetic alteration during burial in the soil.

Such processes may notably account for the lower proportion of betulin $\mathbf{2}$ in the archaeological sample as compared to the large predominance of $\mathbf{2}$ in fresh birch bark (Fig. 3; Hayek et al., 1989), as well as for the absence of betulonal $\mathbf{7}$ and betulinic acid $\mathbf{8}$ - two native triterpenoids from birch bark (cf. sample B; Fig. 3)- in the archaeological material (Fig. 2).

In parallel with the absence of some genuine lupane-related triterpenoids from birch bark, three families of triterpenes likely resulting from alteration processes were detected in sample A. They comprise A-neo-triterpenoids (e.g., 9, 10), $\Delta^{2}$ triterpenoids (e.g., 12, 13), and allobetulane derivatives (e.g., 14-16). $\Delta^{2}$ lupane-derivatives 12 and 13 detected in samples A, $\mathrm{C}$ and D most likely originate from the thermally-induced dehydration of lupeol $\mathbf{1}$ and betulin 2 and can be considered as typical pyrolytic compounds. Their formation was observed, notably, during a controlled pyrolysis experiment of birch bark by Regert et al. (2006) and they generally occur in archaeological birch bark tars (e.g. Binder et al., 1990; Charters et al., 1993; Avelling and Heron, 1998; Regert et al., 2003; Rageot et al., 2015).

Allobetulane derivatives $(\mathbf{1 1}, \mathbf{1 4 - 1 6}$; mass spectra in Fig. S1) were also present in samples A, $\mathrm{C}$ and D. These compounds are postulated to be formed by an acid-catalysed intramolecular rearrangement of ring $E$ (Green et al., 2007; Salvador et al., 2009). Since these compounds exclusively occur in tars (sample D) and not in birch bark (sample B), they are thus considered, like $\Delta^{2}$ derivatives, to be closely associated to the thermal alteration undergone by 


\section{Version avant révision}

birch bark during tar preparation (cf. Heron et al., 1999; Rageot et al., 2015). The acid catalysis necessary for the intramolecular rearrangement of ring $E$ might have been provided by phenols formed by the pyrolytic degradation of lignin (Faix et al., 1990).

The A-neo-triterpenoids found in sample A (9 and 10; MS data shown in Fig. S2 in Supplementary data) and in the reference thermally-treated samples C and D (9-11) derive, respectively, from lupeol $\mathbf{1}$, betulin 2 and allobetulin 16 by contraction of ring $A$. Their formation most likely involves the acid-catalysed loss of the C-3 alcohol moiety followed by a Wagner-Meerwein rearrangement (Salvador et al., 2009). To our knowledge, these compounds have not been reported from fresh birch bark and might have two distinct origins. They can be formed during the preparation of the tar as shown by Rageot (2015) in the case of birch bark tars prepared in the laboratory, the acid catalysis necessary for their formation being possibly induced, as mentioned above, by phenols formed upon lignin pyrolysis (Faix et al., 1990). In addition, Rageot (2015) has shown that their relative abundance is correlated with the experimental conditions, higher temperatures or longer heating periods likely favoring their formation. Nevertheless, the detection of A-neo-triterpenoids, even in small amounts, in the altered birch bark sample B indicates that natural alteration processes may also account to some extent for their formation (ten Haven et al., 1992).

\subsection{Input of conifer resin attested by diterpenoids}

Besides the predominant lupane-related triterpenoids reported above, GC-MS analysis of the organic extract of the substance from the pendant (sample A) revealed an additional contribution of small amounts of early eluted compounds corresponding to diterpenoids. They comprise di-dehydroabietic acid 17, dehydroabietic acid 18, 7-oxodehydroabietic acid 19 along with the related compounds $\mathbf{2 0}$ and $\mathbf{2 1}$ bearing a hydroxyl function at C-15. All of them derive from abietic acid $\mathbf{2 2}$, a diterpenic acid ubiquitously found in conifer resins (Otto 


\section{Version avant révision}

and Wilde, 2001) and especially abundant in resins from Pinaceae (Otto et al., 2007). The contribution of these diterpenoids revealed thus the presence of conifer material in the archaeological substance which could either correspond to a raw resin or a tar made by dry distillation of conifer wood (e.g. Evershed et al., 1985; Connan and Nissenbaum, 2003; Bailly, 2015). However, in the case of conifer tars, aromatic diterpenoids like retene 23 resulting from the thermal transformation of resinic acids upon pyrolysis are generally abundant. In the present case, such compounds could not be detected, suggesting that the use of a conifer tar can be ruled out. Thus, the ingredient corresponds most likely to a conifer resin. In addition, the identification of oxidized derivatives of $\mathbf{1 8}$, comprising compounds with a ketone at C-7 (19 and 21) or a hydroxyl group at C-15 (20 and 21), suggests that the resin was severely altered by oxidative processes during the ageing of the adhesive substance (Colombini et al., 2005; Osete-Cortina and Doménech-Carbó, 2005; Bailly, 2015).

\subsection{Mode of preparation of the adhesive - Origin of the conifer resin component}

The presence of lupane-related biomarkers which have obviously undergone thermal alteration (formation of $\Delta^{2}$-triterpenoids and allobetulane derivatives, notably; see above) in sample A clearly indicates that the organic substance corresponds to an adhesive material (birch bark tar) used to assemble the pendant. However, the contribution of small proportions of conifer resin raises the question whether the addition of the latter was intentional or was the result of a "contamination" during birch bark tar preparation. Indeed, a few examples of mixtures of archaeological birch bark tar containing additional substances have been reported by several authors. These substances comprise animal fat, beeswax, plant oil (Dudd and Evershed, 1999; Regert et al., 2003; van Gijn and Boon, 2006; Rageot et al., 2015) and, in some rare cases, conifer resin/tar (Stacey, 2004; Rageot et al., 2015). The input of additional substances can sometimes be intentional in order to improve the properties of the material. 


\section{Version avant révision}

167 For instance, the addition of beeswax to birch bark tar leads to a substance which is less brittle than pure birch bark tar (Regert et al., 2003; van Gijn and Boon, 2006). It is interesting also to note that Stacey (2004) and Rageot et al. (2015) reported the identification of adhesives very similar in molecular composition to sample A, and which consisted of small amounts of conifer resin mixed with birch bark tar. They were used, respectively, for gluing coral studs on strap unions from harness fittings (Stacey, 2004) and for the reparation of pottery (Rageot et al., 2015). This supports the hypothesis that the admixture of small amounts of conifer resin to birch bark tar might possibly improve its performances as an adhesive and that such mixtures have been prepared on purpose for this specific application.

However, based on the relatively small contribution of the conifer resin as compared to the birch bark tar in the case of sample A, it cannot be excluded that the container used for the storage or the production of birch bark tar may have served previously to collect or store a conifer resin and might have thus contaminated the birch bark tar. It should however be mentioned that the relatively low proportion of diterpenes relative to triterpenes observed in sample A does not necessarily reflect the initial proportions of conifer resin and birch bark tar making up the adhesive. Indeed, resinic acids might be significantly more sensitive to oxidative alteration given the presence of reactive benzylic positions on dehydroabietic acid 18 and related structures as illustrated by the detection of several oxidized dehydroabietic acid derivatives (19-21) in sample A. The presence of several oxygenated functionalities on these structures might thus be responsible for an enhanced water solubility as compared to lupane-related triterpenoids, thus favouring their progressive removal by leaching, notably after burial.

\section{Conclusion}




\section{Version avant révision}

190

191

192

193

194

195

196

197

198

199

200

201

202

203

204

205

206

207

208

209

210

211

212

213

214

215

216

217

218

Identification of triterpenoids from the lupane series in the organic material found on an archaeological necklace pendant clearly indicates that this substance was made predominantly of birch bark tar, together with a small contribution of conifer resin. This material likely corresponds to an adhesive that could have served to fix a decorative item on the pendant. The question remains regarding the role of the conifer resin which could either be part of the ingredients added intentionally to improve the quality of the adhesive material, or correspond to a "contamination" introduced during birch bark tar preparation.

\section{Acknowledgement}

We thank A. Kurzweil for the birch bark tar reference sample produced according to traditional techniques (Museumsdorf Düppel, Berlin). The INRAP is thanked for providing the archaeological sample. B.C. thanks the French Ministère de l'Enseignement Supérieur et de la Recherche for a doctoral fellowship.

\section{Appendix}

\section{References}

Aveling, E.M., Heron, C., 1998. Identification of birch bark tar at the Mesolithic site of Star Carr. Anc. Biomol. 2, 69-80.

Aveling, E.M., Heron, C., 1999. Chewing tar in the early Holocene: an archaeological and ethnographic evaluation. Antiquity 73, 579-584.

Bailly, L., 2015. Caractérisation moléculaire et isotopique de goudrons et résines archéologiques dérivés de conifères en contexte maritime. $\mathrm{PhD}$ thesis, Université de Strasbourg, France.

Beck, P., Caudullo, G., de Rigo, D., Tinner, W., 2016. Betula pendula, Betula pubescens and other birches in Europe: distribution, habitat, usage and threats, in: San-Miguel- Ayanz, J., de Rigo, D., Caudullo, G., Houston Durrant, T., Mauri, A. (Eds.), European Atlas of Forest Tree Species. Publ. Off. EU, Luxembourg, pp. 70-73.

Binder, D., Bourgeois, G., Benoist, F., Vitry, C., 1990. Identification de brai de bouleau (Betula) dans le Néolithique de Giribaldi (Nice, France) par la spectrométrie de masse. ArcheoSciences 14, 37-42. 


\section{Version avant révision}

219 Charters, S., Evershed, R.P., Goad, L.J., Heron, C., Blinkhorn, P.W., 1993. Identification of an adhesive used to repair a Roman jar. Archaeometry 35, 91-101.

221 Colombini, M.P., Modugno, F., Ribechini, E., 2005. Direct exposure electron ionization mass 222 spectrometry and gas chromatography/mass spectrometry techniques to study organic coatings on archaeological amphorae. J. Mass Spectrom. 40, 675-687.

224 Connan, J., Adam, P., Dessort, D., Albrecht, P., 2000. Apport de la chimie moléculaire à la connaissance des enduits utilisés pour le traitement des bois et le calfatage des bateaux romains de la Saône, in: Bonnamour, L. (Ed.), Archéologie des fleuves et des rivières. Editions Errance, Paris, pp. 40-47.

Connan, J., Nissenbaum, A., 2003. Conifer tar on the keel and hull planking of the Ma'agan Mikhael Ship (Israel, $5^{\text {th }}$ century BC): identification and comparison with natural products and artefacts employed in boat construction. J. Archaeol. Sci. 30, 709-719.

Dudd, S.N., Evershed, R.P., 1999. Unusual triterpenoid fatty acyl ester components of archaeological birch bark tars. Tetrahedron Lett. 40, 359-362.

Evershed, R.P., Jerman, K., Eglinton, G., 1985. Pine wood origin for pitch from the Mary Rose. Nature 314, 528-530.

Faix, O., Meier, D., Fortmann, I., 1990. Thermal degradation products of wood. Holz Roh. Werkst. 48, 351-354.

Green, B., Bentley, M.D., Chung, B.Y., Lynch, N.G., Jensen, B.L., 2007. Isolation of betulin and rearrangement to allobetulin. A biomimetic natural product synthesis. J. Chem. Educ. 84, 1985-1987.

Hayek, E.W.H., Jordis, U., Moche, W., Sauter, F., 1989. A bicentennial of betulin. Phytochemistry 28, 2229-2242.

Hayek, E.W.H., Krenmayr, P., Lohninger, H., Jordis, U., Moche, W., Sauter, F., 1990. Identification of archaeological and recent wood tar pitches using gas chromatography/mass spectrometry and pattern recognition. Anal. Chem. 62, 2038-2043.

Heron, C., Aveling, E.M., Challinor, C., Derham, B., Stacey, R.J., Stern, B., 1999. Chromatography in archaeology. Chromatogr. Sep. Technol. 5, 4-8.

247 Karg, S., Hansen, U.L., Walldén, A.M., Glastrup, J., Ærenlud Pedersen, H., Sonne Nielsen, 248 F.O., 2014. Vegetal grave goods in a female burial on Bornholm (Denmark) from the Late 249 Roman Iron Age period interpreted in a comparative European perspective. J. Danish 250 Archaeol. 3, 52-60. manufactured pitch identified. Eur. J. Archaeol. 4, 385-397. 


\section{Version avant révision}

Osete-Cortina, L., Doménech-Carbó, M.T., 2005. Analytical characterization of diterpenoid resins present in pictorial varnishes using pyrolysis-gas chromatography-mass spectrometry with on line trimethylsilylation. J. Chromatogr. A 1065, 265-278.

Otto, A., Wilde, V., 2001. Sesqui-, di-, and triterpenoids as chemosystematic markers in extant conifers - a review. Bot. Rev. 67, 141-238.

Otto, A., Simoneit, B.R.T., Wilde, V., 2007. Terpenoids as chemosystematic markers in selected fossil and extant species of pine (Pinus, Pinaceae). Bot. J. Linn. Soc. 154, 129-140.

Rageot, M., 2015. Les substances naturelles en Méditerranée nord-occidentale (VI ${ }^{\text {ème }}-\mathrm{I}^{\text {er }}$ Millénaire BCE): Chimie et archéologie des matériaux exploités pour leurs proprietés adhésives et hydrophobes. PhD Thesis, Université de Nice Sophia-Antipolis, France.

Rageot, M., Pêche-Quilichini, K., Py, V., Filippi, J.-J., Fernandez, X., Regert, M., 2015. Exploitation of beehive products, plant exudates and tars in Corsica during the Early Iron Age. Archaeometry 58, 315-332.

Regert, M., Delacorte, J.-M., Menu, M., Petrequin, P., Rolando, C., 1998. Identification of Neolithic hafting adhesives from two lake dwellings at Chalain (Jura, France). Anc. Biomol. 2, 81-96.

Regert, M., Vacher, S., Moulherat, C., Decavallas, O., 2003. Adhesive production and pottery function during the Iron Age at the site of Grand Aunay (Sarthe, France). Archaeometry 45, 101-120.

Regert, M., Alexandre, V., Thomas, N., Lattuati-Derieux, A., 2006. Molecular characterisation of birch bark tar by headspace solid-phase microextraction gas chromatography-mass spectrometry: a new way for identifying archaeological glues. J. Chromatogr. A 1101, 245-253.

Salvador, J.A.R., Pinto, R.M.A., Santos, R.C., Le Roux, C., Beja, A.M., Paixão, J.A., 2009. Bismuth triflate-catalyzed Wagner-Meerwein rearrangement in terpenes. Application to the synthesis of the $18 \alpha$-oleanane core and A-neo-18 $\alpha$-oleanene compounds from lupane. Org. Biomol. Chem. 7, 508-517.

Schnell, G., Schaeffer, P., Tardivon, H., Motsch, E., Connan, J., Ertlen, D., Schwartz, D., Schneider, N., Adam, P., 2014. Contrasting diagenetic pathways of higher plant triterpenoids in buried wood as a function of tree species. Org. Geochem. 66, 107-124.

Stacey, R., 2004. Evidence for the use of birch-bark tar from Iron Age Britain. Past14, 1-2.

ten Haven, H.L., Peakman, T.M., Rullkötter, J., 1992. Early diagenetic transformation of higher-plant triterpenoids in deep-sea sediments from Baffin Bay. Geochim. Cosmochim. Acta 56, 2001-2024.

Trąbska, J., Wesełucha-Birczyńska, A., Zięba-Palus, J., Runge, M.T., 2011. Black painted pottery, Kildehuse II, Odense County, Denmark. Spectrochim. Acta A 79, 824-830. 


\section{Version avant révision}

290 Urem-Kotsou, D., Stern, B., Heron, C., Kotsakis, K., 2002. Birch-bark tar at Neolithic

291 Makriyalos, Greece. Antiquity 76, 962-967.

292 Van Gijn, A.L., Boon, J.J., 2006. Birch bark tar, in: Louwe Kooijmans, L.P., Jongste, P.F.B. 293 (Eds.), Schipluiden. A Neolithic settlement on the Dutch North Sea coast c. 3500 cal. BC, 294 Analecta Praehistorica Leidensia, 37/38, Faculty of Archaeology, Leiden University, Leiden, 295 pp. 261-266.

296 Vogt, E., 1949. The birch as a source of raw material during the Stone Age. P. Prehist. Soc. $297 \quad 15,50-51$.

298

299

Figure captions

300

Figure 1. Necklace (a) with a pendant (b) found among the furniture and artefacts of a tomb

301 dated to the Hallstatt D1 period (625-550 BC; Eckwersheim, NE France). Photos and 302 drawing by $\odot$ Y. Thomas, INRAP.

Figure 2. Gas chromatogram of the lipid extract of the adhesive of the necklace pendant (sample A). Bold numbers refer to the structures shown in Appendix. Alcohols are analyzed as acetates and carboxylic acids as methyl esters.

306

Figure 3. Gas chromatograms of the organic extract of (a) altered birch bark sample (sample 307 B); (b) altered birch bark sample after pyrolysis (sample C); (c) reference birch bark tar prepared by descending distillation (sample D). Bold numbers refer to the structures shown in Appendix. Alcohols are analyzed as acetates and carboxylic acids as methyl esters. 


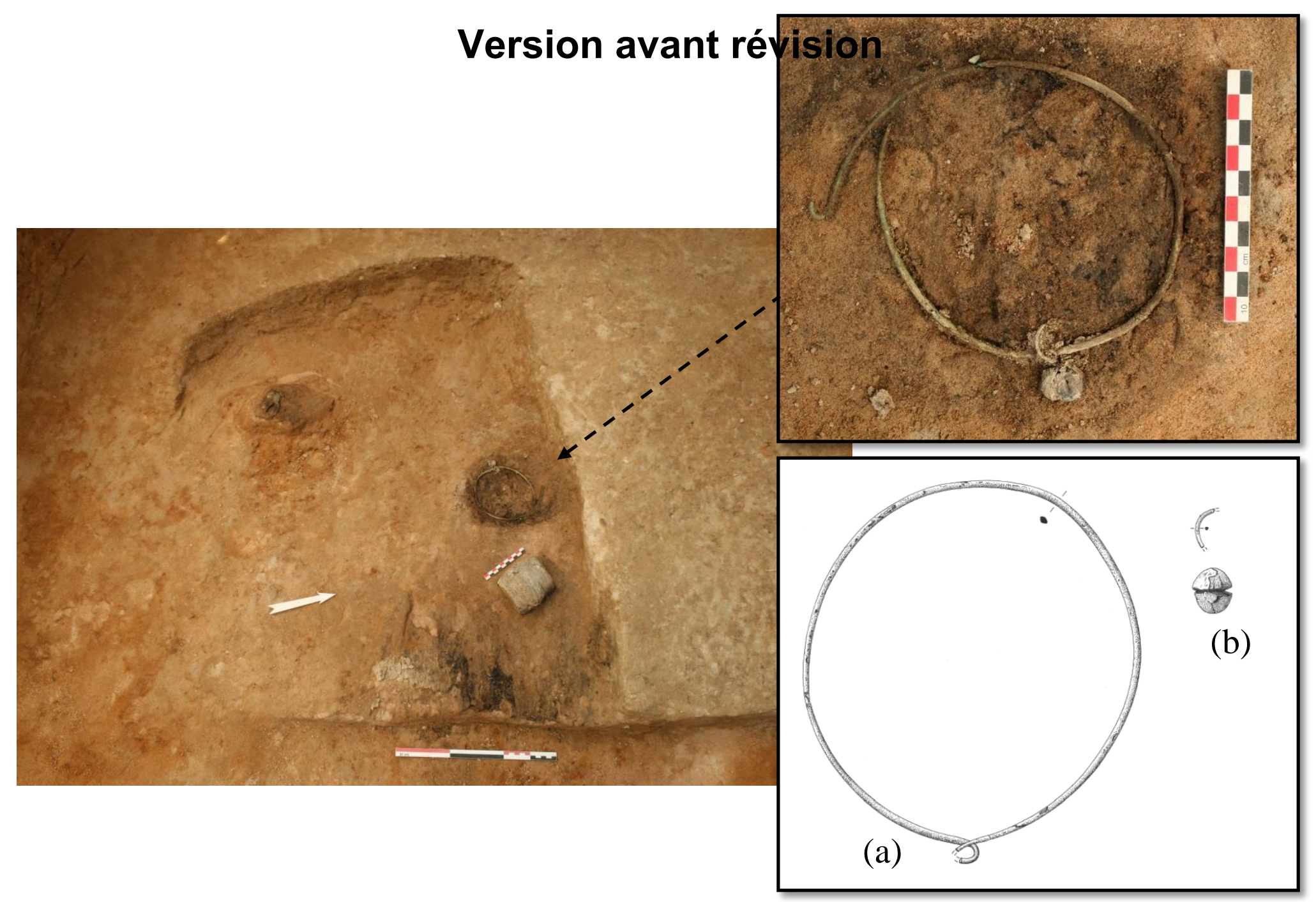

Figure 1 


\section{Version avant révision}

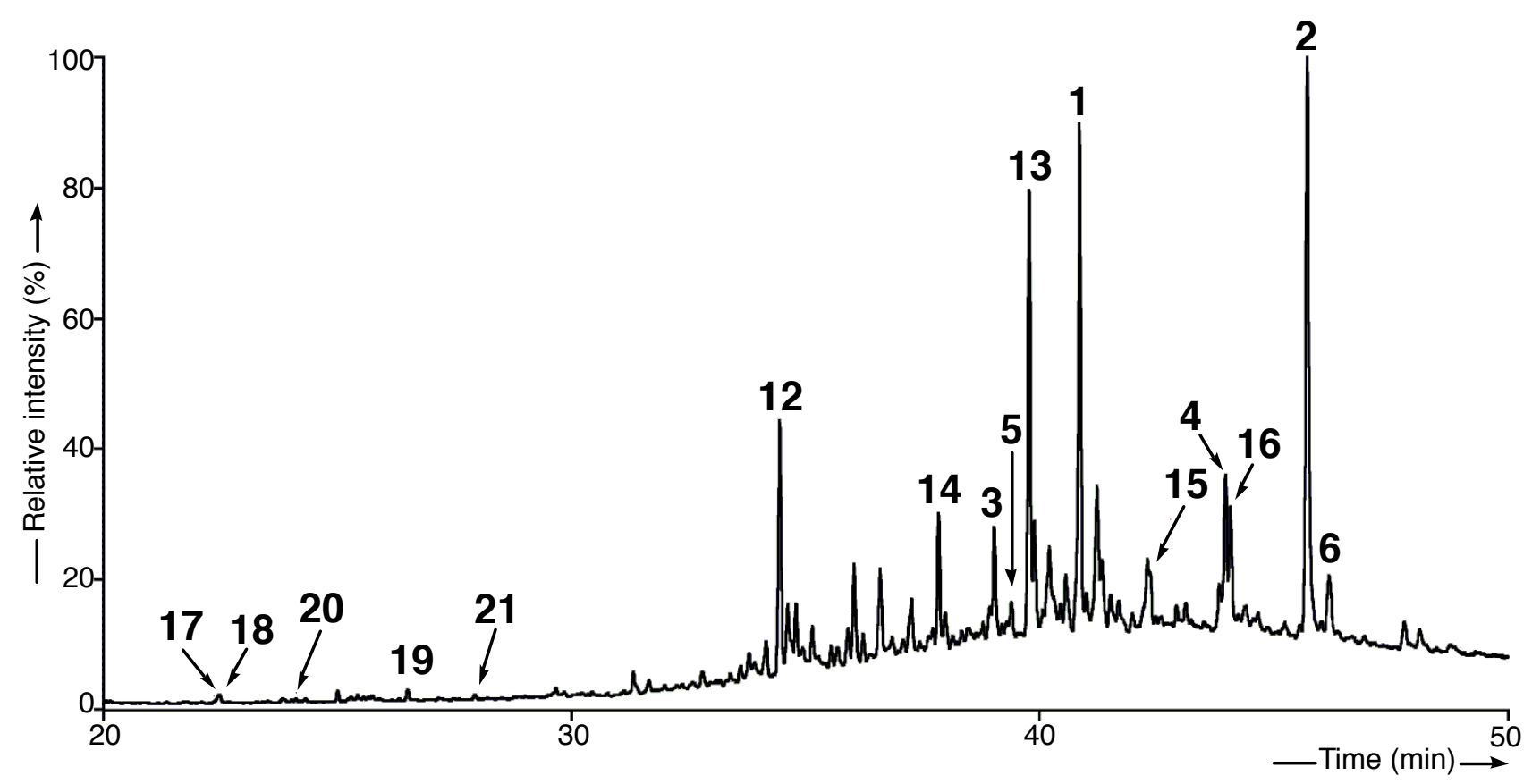

Figure 2 


\section{Version avant révision}
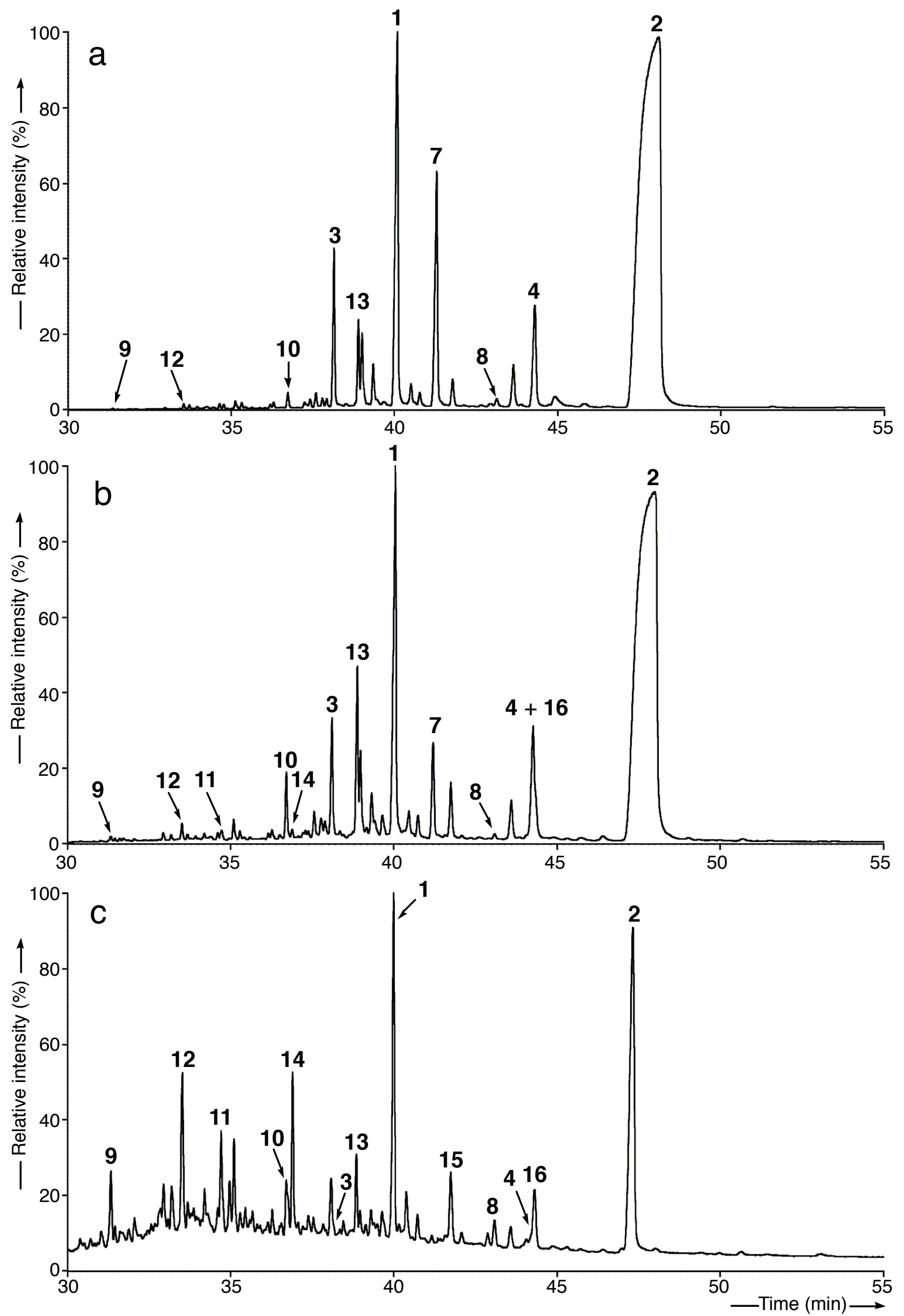

Figure 3 


\section{Version avant révision}

\section{Appendix}

Structures cited in the text

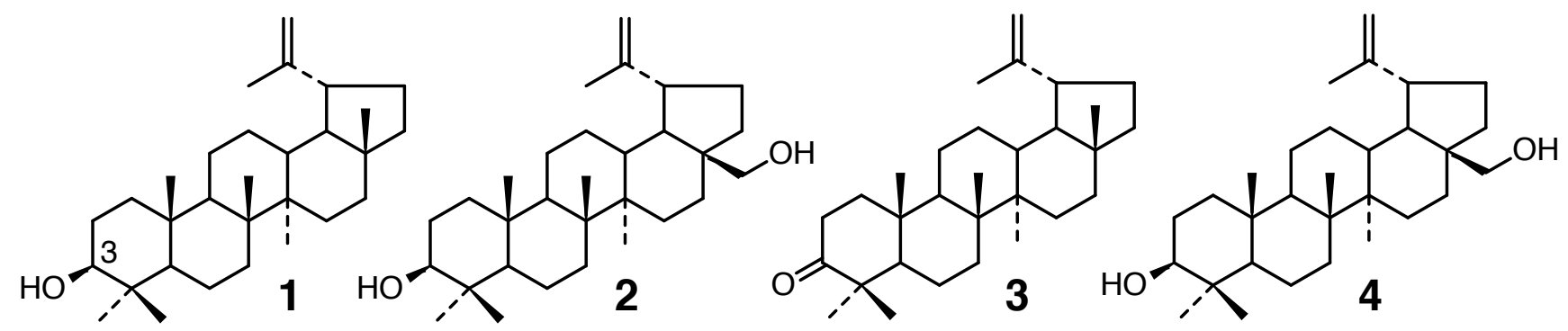

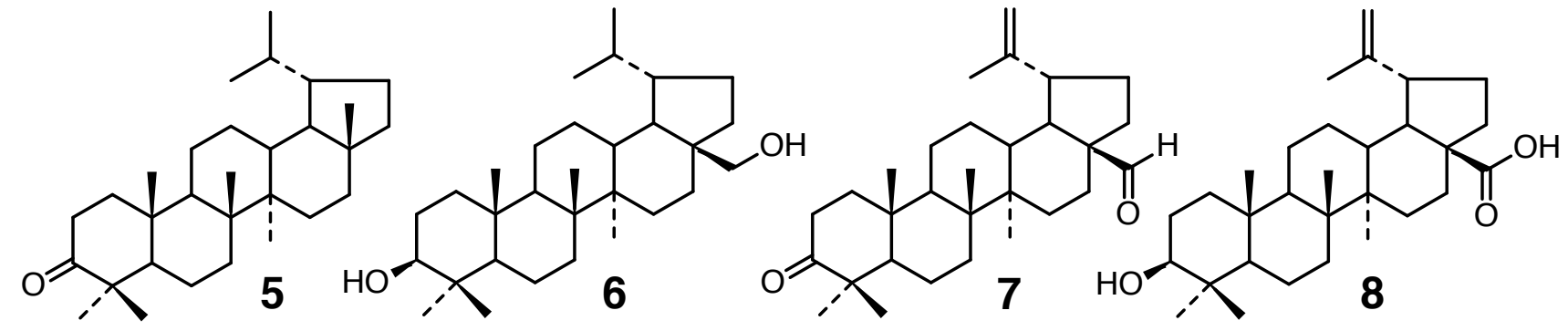

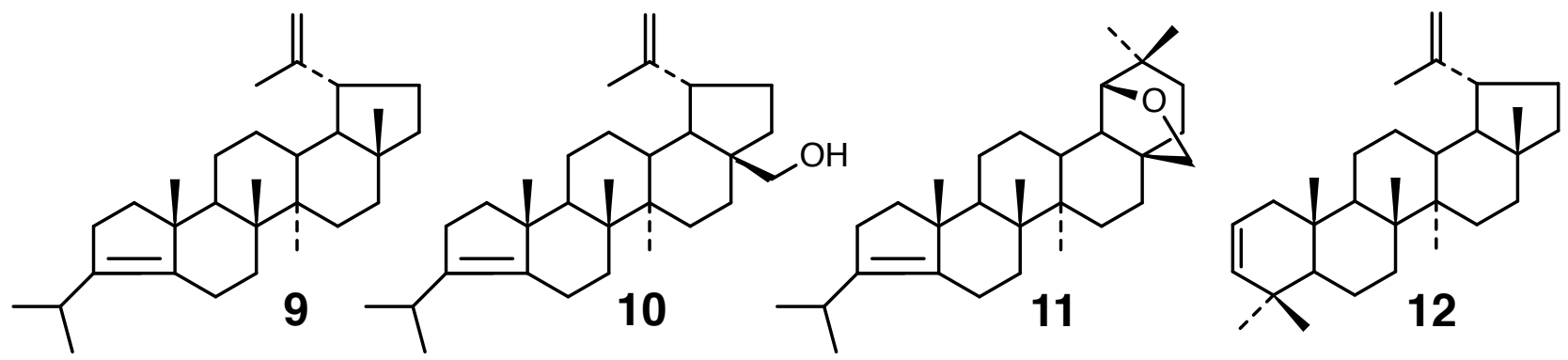

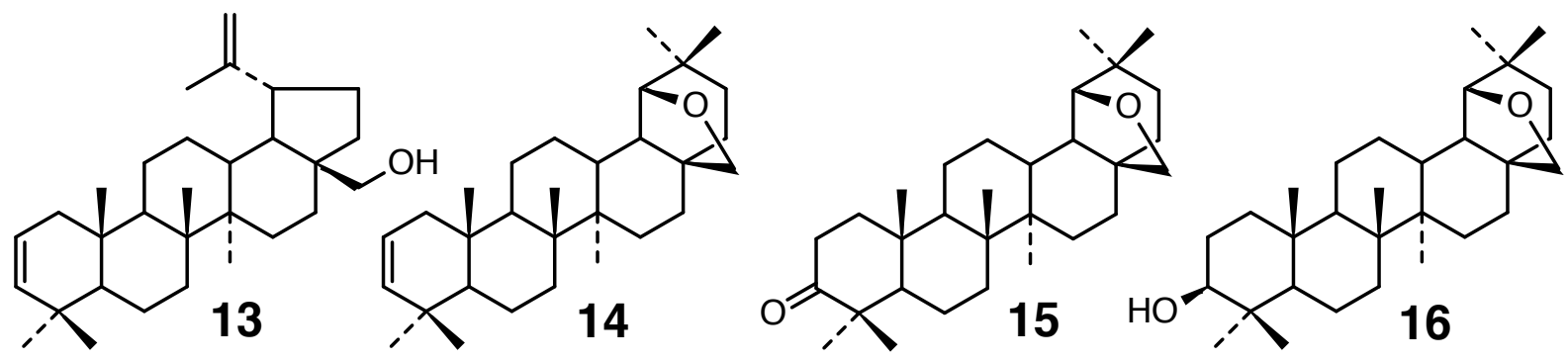<smiles>CC(C)c1ccc2c(c1)C1CCCC(C)(C)C1CCC2</smiles><smiles>CC(C)c1ccc2c(c1)CC1C3(C)CCCC2(C)C1(O)C3</smiles><smiles>CC(C)c1ccc2c(c1)C(=O)CC1C(C)(C)CCCC21C(=O)O</smiles><smiles></smiles>

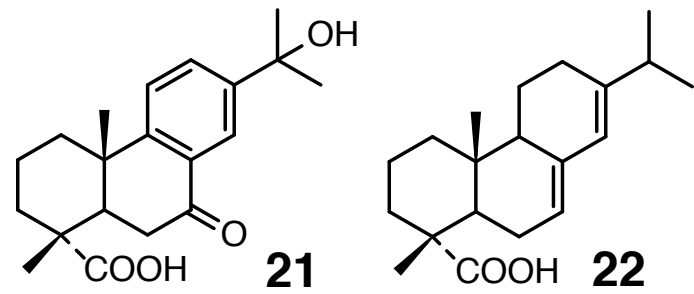<smiles>Cc1ccc2ccc(C(C)C)cc2c1</smiles> 


\section{Version avant révision}

\section{Birch bark tar and jewellery: the case study of a necklace from the Iron}

Age (Eckwersheim, NE France)

Blandine Courel $^{\mathrm{a},{ }^{*}}$, Philippe Schaeffer ${ }^{\mathrm{a},{ }^{*}}$, Pierre Adam ${ }^{\mathrm{a}}$, Clément Féliu ${ }^{\mathrm{b}, \mathrm{c}}$, Yohann Thomas ${ }^{\mathrm{b}}$

${ }^{a}$ Université de Strasbourg, CNRS, CHIMIE, UMR 7177, F-67000 Strasbourg, France ${ }^{b}$ INRAP Grand-Est, F-67100 Strasbourg, France

${ }^{c}$ Université de Strasbourg, Université de Haute Alsace, CNRS, ArchIMèdE UMR 7044, F67000 Strasbourg, France

\section{Supplementary materials}

- Figure S1: Mass spectra (EI, $70 \mathrm{eV}$ ) of allobetulane derivatives 11, 14-16.

- Figure S2: Mass spectra (EI, $70 \mathrm{eV}$ ) of A-neo-triterpenoids of the lupane series 9 and $\mathbf{1 0}$ found in the archaeological sample (sample A) and in the thermally-treated reference samples (samples B and C). 


\section{Version avant révision}

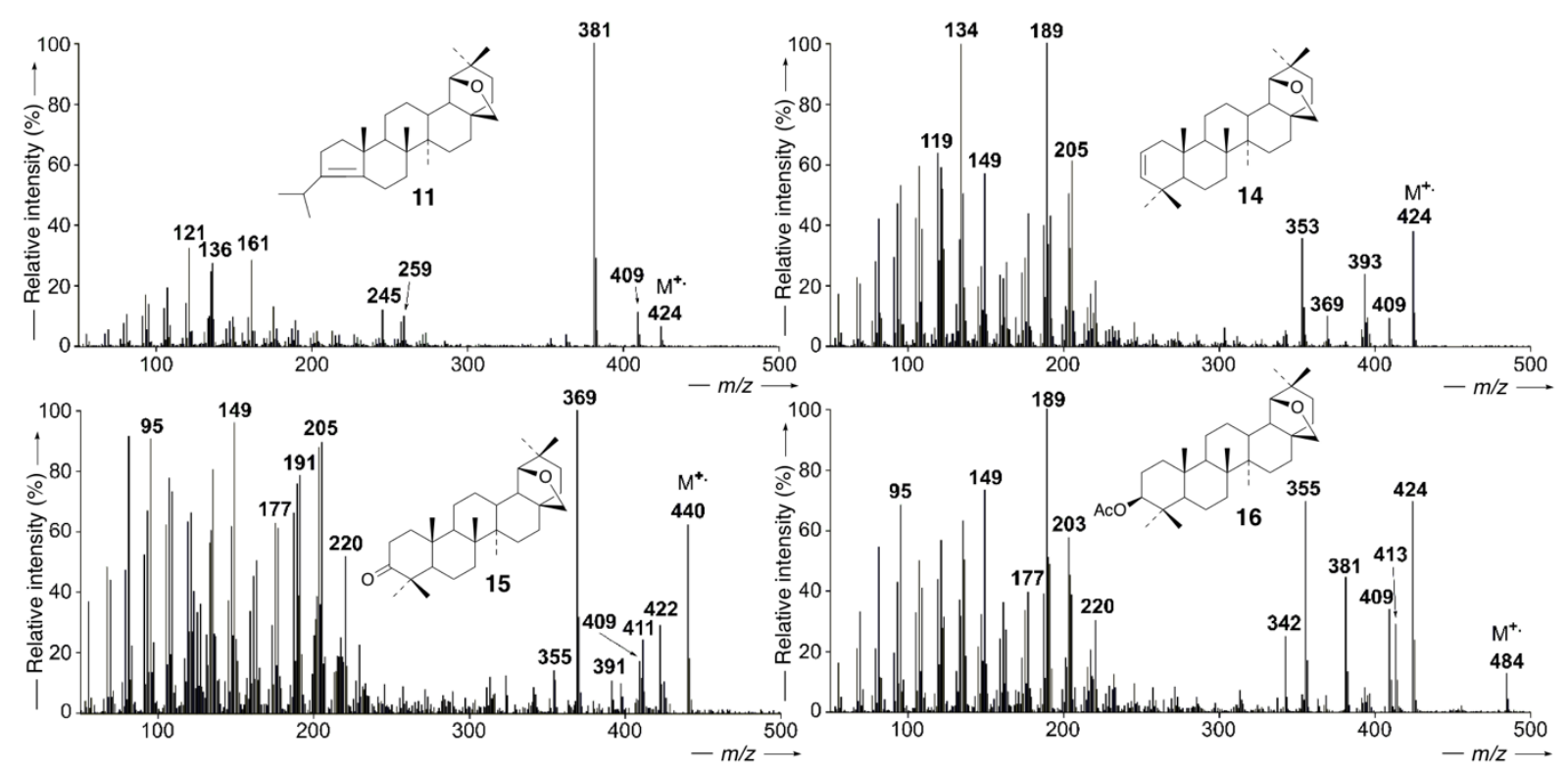

Figure S1: Mass spectra (EI, $70 \mathrm{eV}$ ) of allobetulane derivatives 11, 14-16. Bold numbers refer to the structures shown in the Appendix. 


\section{Version avant révision}

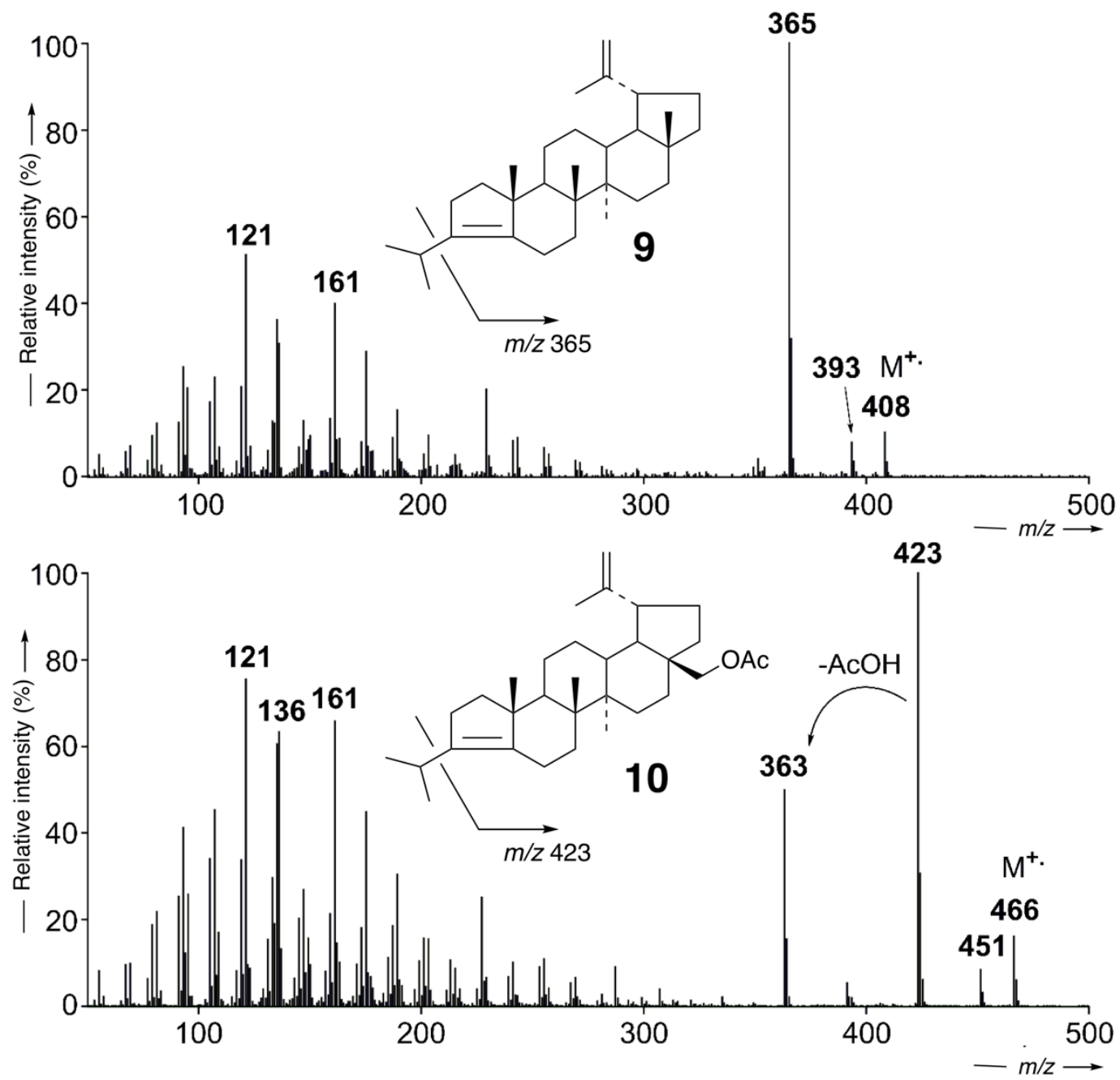

Figure S2: Mass spectra (EI, $70 \mathrm{eV}$ ) of $A$-neo-triterpenoids of the lupane series $\mathbf{9}$ and $\mathbf{1 0}$ found in the archaeological sample (sample A) and in the thermally-treated reference samples (samples B and C). Bold numbers refer to the structures shown in the Appendix. 